\title{
Halogenation as a Strategy to Improve Antiplasmodial Activity: A Report of New 3-Alkylpyridine Marine Alkaloid Analogs
}

\author{
Camila de Souza Barbosa ${ }^{1}$, Daniel Silqueira Martins Guimarães ${ }^{2}$, Juliana da Costa Alves ${ }^{1}$, Cristiana Ferreira \\ Alves de Brito ${ }^{2}$, Renato Márcio Ribeiro-Viana ${ }^{3}$, Fernando de Pilla Varotti ${ }^{1 *}$, Gustavo Henrique Ribeiro Viana ${ }^{1 *}$ \\ ${ }^{1}$ Núcleo de Pesquisa em Química Biológica, Universidade Federal de São João Del-Rei, Campus Centro Oeste, \\ Divinópolis, MG 35501-296, Brazil \\ ${ }^{2}$ Instituto René Rachou, Fundação Oswaldo Cruz, Belo Horizonte, MG 30190-009, Brazil \\ ${ }^{3}$ Departamento Acadêmico de Química (DAQUI), Universidade Tecnológica Federal do Paraná, 86036-370 Londrina, \\ Paraná, Brazil \\ Corresponding Authors: Fernando de Pilla Varotti, PhD, Professor, Núcleo de Pesquisa em Química Biológica, \\ Universidade Federal de São João Del-Rei, Campus Centro Oeste, Divinópolis, MG 35501-296, Brazil. Tel: +55- \\ 37991360377,Email: varotti@ufsj.edu.br; \\ Gustavo Henrique Ribeiro Viana, PhD, Professor, Núcleo de Pesquisa em Química Biológica, Universidade Federal de São \\ João Del-Rei, Campus Centro Oeste, Divinópolis, MG 35501-296, Brazil. Tel: +55-3732211610, Email: viana@ufsj.edu.br
}

Received August 18, 2019; Accepted November 29, 2019; Online Published December 15, 2019

\begin{abstract}
Introduction: Due to the emergence of resistance to antimalarial drugs as well as the lack of vaccination for malaria, there is an urgent demand for the development of new antimalarial alternatives. Recently, our research group developed a new set of 3-alkylpyridine marine alkaloid analogs, of which a compound known as compound 5 was found to be inactive against Plasmodium falciparum.

Methods: Herein, we report a successful halogenation strategy to improve the antiplasmodial activity of compound 5 through the replacement of a hydroxyl group by chlorine (compound 6) and fluorine (compound 7) atoms.

Results: Compounds 6 and 7 showed improved antiplasmodial activities $\left(\mathrm{IC}_{50}=7.2\right.$ and $8.3 \mu \mathrm{M}$, respectively) 20 times higher than that of their precursor, compound $5\left(\mathrm{IC}_{50}=210.7 \mu \mathrm{M}\right)$. Ultraviolet-visible titration experiments demonstrated that halogenation of compound 5 did not alter its ability to bind its target, hematin.

Conclusion: Halogenation can enhance the antiplasmodial activity of a compound without altering its mechanism of action. Keywords: Plasmodium falciparum, 3-Alkylpyridine Marine Alkaloid Analogs, Antiplasmodial Activity, Halogenation, Malaria
\end{abstract}

Citation: de Souza Barbosa C, Guimarães DSM, da Costa Alves J, et al. Halogenation as a strategy to improve antiplasmodial activity: a report of new 3-alkylpyridine marine alkaloid analogs. Int J Travel Med Glob Health. 2019;7(4):129-134. doi:10.15171/ijtmgh.2019.27.

\section{Introduction}

According to the World Health Organization (WHO), despite the notable decrease in malaria burden from 2010 to 2015 (from 239 to 214 million cases), a slight increase in the number of malaria cases over the last few years suggests that progress in malaria eradication has stalled. In 2017, an estimated 219 million cases occurred worldwide. In the same year, an estimated 435 thousand deaths globally were attributable to malaria, with children under 5 years of age accounting for $61 \%$ (266.000) of all deaths. ${ }^{1}$ Meanwhile in Brazil, the number of malaria cases increased by $48 \%$ in 2017 compared to $2016 .{ }^{2}$ Malaria in humans is caused by different Plasmodium species: Plasmodium falciparum, Plasmodium vivax, Plasmodium malariae, and Plasmodium ovale. Recently, it was found that humans can also be infected with Plasmodium knowlesi, a species that infects primates. ${ }^{3}$ Clinical manifestations of malaria in humans are associated with its intraerythrocytic cycle. For example, the high rate of sequestration of P. falciparum-infected erythrocytes is a feature of severe $P$. falciparum infection. ${ }^{4}$

There is a high need for the development of new antimalarial agents due to the emergence of parasite drug resistance, including resistance to artemisinin-based combination therapy (ACT) and vector insecticide resistance, as well as the lack of an effective vaccine. ${ }^{5} \mathrm{ACT}$ is the therapy recommended by the WHO for the treatment of uncomplicated falciparum malaria, and there is a broad consensus that its efficacy needs to be protected. ${ }^{1}$

Regarding this concern, an increasing amount of investment is being made by domestic and international sources since

Copyright $(0) 2019$ The Author(s). This is an open-access article distributed under the terms of the Creative Commons Attribution License (http:// creativecommons.org/licenses/by/4.0), which permits unrestricted use, distribution, and reproduction in any medium, provided the original work is properly cited. 
$2000 .{ }^{1}$ As a result, the process of identifying new antimalarial candidates has evolved, leading to 13 new antimalarial drugs in drug development, nine of which were in Phase 2 in $2018 .{ }^{6}$

For the last 7 years, our research group has been studying the antiplasmodial activity of synthetic analogs of theonelladin C, a 3-alkylpyridine marine alkaloid (3-APA), some of which have exhibited promising antiplasmodial activity. ${ }^{7}$ Moreover, by adopting in silico simulation and biophysical techniques, our research group proposed that the mechanism for the antimalarial action of these analogs is through interference with the process of hemozoin formation. ${ }^{8}$

Some 3-APA analogs with a short alkyl chain, however, were considered inactive against $P$. falciparum in vitro (in-house library of compounds). As an example, compound 5 exhibited a high $\mathrm{IC}_{50}$ value $(210.7 \mu \mathrm{M})$ but was found to interact with hematin in a pattern similar to that of chloroquine (CQ) (Figures $1 \mathrm{a}$ and $1 \mathrm{~b}$ ). This paradoxical behavior of compound 5 , its ability to form a complex with hematin, and at the same time, its inactivity against $P$. falciparum suggests its inability to reach its target in vitro.

Starting from this point, in an attempt to improve the permeability of compound $\mathbf{5}$ and, consequently, its ability to reach the parasite's hematin, the hydroxyl group was replaced with chlorine and fluorine atoms (the detailed synthetic route is described in Supporting Information, item 1). This strategy, known as halogenation, may improve some of the compound's pharmacological properties such as membrane permeation, metabolic stability, and target affinity. ${ }^{9}$

\section{Methods}

\section{Chemicals and Reagents}

1,6-hexanediol;3,4-dihydro-2H-pyran(DHP); toluene;sodium hydrogen sulfate $\left(\mathrm{NaHSO}_{4}\right)$; hexane; sodium sulfate $\left(\mathrm{Na}_{2} \mathrm{SO}_{4}\right)$; silica gel $60\left(\mathrm{SiO}_{2}\right)$; ethyl acetate (EtOAc); dichloromethane $\left(\mathrm{CH}_{2} \mathrm{Cl}_{2}\right)$; triethylamine $\left(\mathrm{Et}_{3} \mathrm{~N}\right)$; methanesulfonyl chloride ( $\mathrm{MsCl})$; tetrabutylammonium bromide $\left(\mathrm{Bu}_{4} \mathrm{~N}^{+} \mathrm{Br}^{-}\right)$; diethyl ether $\left(\mathrm{Et}_{2} \mathrm{O}\right)$; sodium hydroxide $(\mathrm{NaOH})$, methanol $(\mathrm{MeOH})$; hydrochloric acid ( $\mathrm{HCl}) ; \quad N$-chlorosuccinimide (NCS); triphenylphosphine $\left(\mathrm{PPh}_{3}\right)$; (diethylamino) sulfur trifluoride (DAST); sodium bicarbonate $\left(\mathrm{NaHCO}_{3}\right)$; RPMI 1640 medium; sorbitol; 1-(4,5-Dimethylthiazol-2-yl)-3,5-diphenylformazan (MTT); fetal bovine serum (FBS); penicillin; streptomycin; dimethylsulfoxide (DMSO); hematin chloride; HEPES; tetramethylsilane (TMS); potassium bromide (KBr); deuterochloroform $\left(\mathrm{CDCl}_{3}\right)$.

\section{Chemistry}

Reagents and solvents were purchased as reagent grade and used without further purification. Nuclear magnetic resonance (NMR) spectra were recorded using a Bruker Avance III $400 \mathrm{MHz}$ spectrometer (Bruker BioSpin GmbH, Rheinstetten, Germany). Chemical shifts are reported as $\delta$ (ppm) downfield from TMS, and the $J$ values are reported in Hz. IR spectra were recorded using a Shimadzu IRAffinity-1 Fourier transform spectrometer (Shimadzu Corp., Kyoto, Japan). Low-resolution mass spectra (LRMS) were recorded using an ESI Bruker Daltonics amaZon SL Ion Trap mass spectrometer (Bruker Daltonics, Bremen, Germany). Column chromatography was performed with $\mathrm{SiO}_{2}, 70-230$ mesh (Merck, Darmstadt, Germany).

Procedure for the Synthesis of 6-(oxan-2-yloxy)hexan-1ol (2)

A mixture of 1,6-hexanediol 1 (1.0 equiv.), DHP-toluene (5\% v/v) (1,96 equiv.), and aqueous $5 \mathrm{M} \mathrm{NaHSO}_{4}(0.1 \mathrm{~mL})$ was prepared. This mixture was stirred for at $30{ }^{\circ} \mathrm{C}$ for 3 hours and then extracted with hexane ( 3 times). The combined organic phases were dried with $\mathrm{Na}_{2} \mathrm{SO}_{4}$, filtered, and then evaporated under reduced pressure. The residue obtained was chromatographed $\left(\mathrm{SiO}_{2}\right.$, hexane/EtOAc 80:20) to yield pure compound 2 .

6-(oxan-2-yloxy)hexan-1-ol 2: Yield 79\%, $R f=0.29$ (hexane/EtOAc 80:20), colorless oily product: IR (KBr): $\bar{v}=$ $3398,2939,2865,1406,1440,1138,1120,857 \mathrm{~cm}^{-1} .{ }^{1} \mathrm{H}$ NMR
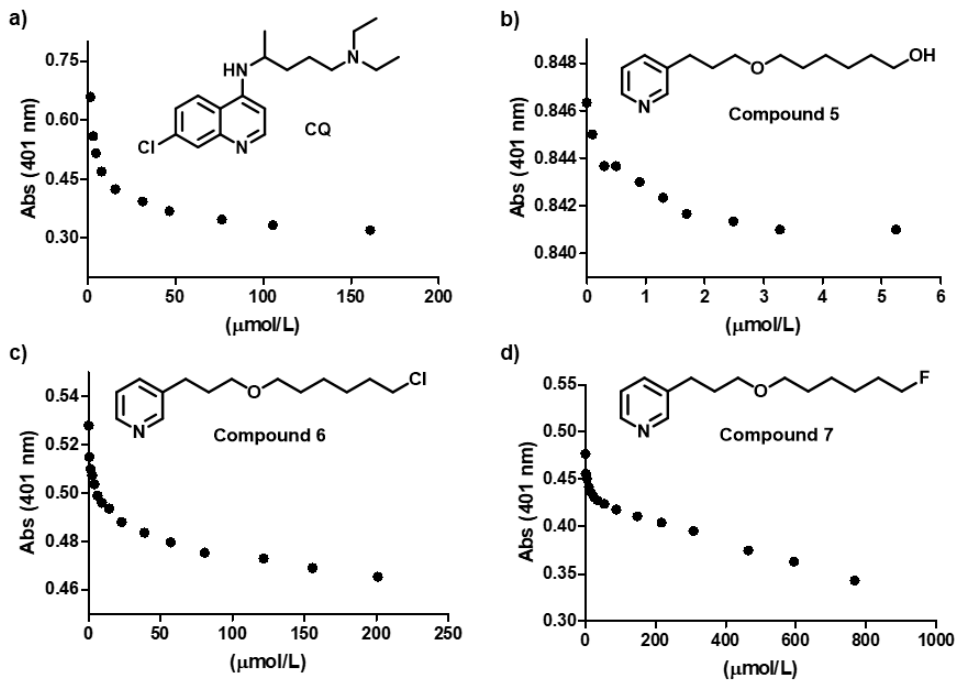

Figure 1. Titration of Hematin $(5.0 \mu \mathrm{mol} / \mathrm{L})$ With Increasing Concentrations of a) CQ $(0-161.0 \mu \mathrm{mol} / \mathrm{L})$ (inset shows a plot of absorbance at $401 \mathrm{~nm}$ versus the concentration of CQ); b) compound $5(0-5.24 \mu \mathrm{mol} / \mathrm{L}$ ) (inset shows a plot of absorbance at $401 \mathrm{~nm}$ versus the concentration of compound 5); c) compound 6 (0-201.0 $\mu$ mol/L) (inset shows a plot of absorbance at $401 \mathrm{~nm}$ versus the concentration of compound 6); and d) compound 7 (0-767.0 $\mu$ mol/L) (inset shows a plot of absorbance at $401 \mathrm{~nm}$ versus the concentration of compound 7). 
$\left(\mathrm{CDCl}_{3}, 400 \mathrm{MHz}\right): \delta 1.33-1.42(\mathrm{~m}, 4 \mathrm{H}), 1.50-1.61(\mathrm{~m}, 8 \mathrm{H})$, 1.69-1.75 (m, 1H), 1.79-1.87 (m, $1 \mathrm{H}), 3.39(\mathrm{dt}, 1 \mathrm{H}, J=9.6 \mathrm{~Hz}$, $J=6.5 \mathrm{~Hz}), 3.48-3.53(\mathrm{~m}, 1 \mathrm{H}), 3.64(\mathrm{t}, 2 \mathrm{H}, J=6.6 \mathrm{~Hz}), 3.74$ $(\mathrm{dt}, 1 \mathrm{H}, J=9.6 \mathrm{~Hz}, J=6.8 \mathrm{~Hz}), 3.84-3.90(\mathrm{~m}, 1 \mathrm{H}), 4.57(\mathrm{t}, 1 \mathrm{H}$, $J=2.6 \mathrm{~Hz}) \mathrm{ppm} .{ }^{13} \mathrm{C} \mathrm{NMR}\left(\mathrm{CDCl}_{3}, 100 \mathrm{MHz}\right): \delta 19.69,25.45$, $25.52,26.00,29.65,30.75,32.66,62.85,67.49,98.88 \mathrm{ppm}$. LRMS (ESI) $m / z 225.0[\mathrm{M}+\mathrm{Na}]^{+}$.

Procedure for the Synthesis of 6-(oxan-2-yloxy)hexyl methanesulfonate (3)

A solution of monotetrahydropyranyl acetal 2 (1.0 equiv.) in $\mathrm{CH}_{2} \mathrm{Cl}_{2}(50 \mathrm{~mL})$ was cooled to $0^{\circ} \mathrm{C}$. $\mathrm{Et}_{3} \mathrm{~N}$ (4.0 equiv.), and $\mathrm{MsCl}$ (2.0 equiv.) was added. The reaction mixture was stirred for 24 hours at room temperature and then poured into crushed ice and extracted with $\mathrm{CH}_{2} \mathrm{Cl}_{2}$ (3 times). The organic layer was dried with $\mathrm{Na}_{2} \mathrm{SO}_{4}$, filtered, and evaporated under reduced pressure. The residue obtained was purified by column chromatography $\left(\mathrm{SiO}_{2}\right.$, hexane/EtOAc $\left.1: 1\right)$ to yield pure compound 3.

6-(oxan-2-yloxy)hexyl methanesulfonate 3: Yield 82\%, $R f=$ 0.25 (hexane/EtOAc 80:20), yellow oily product: IR (KBr): $\bar{v}$ $=2929,2865,1420,1354,1174,1124,1122,856 \mathrm{~cm}^{-1} .{ }^{1} \mathrm{H}$ NMR $\left(\mathrm{CDCl}_{3}, 400 \mathrm{MHz}\right): \delta 1.37-1.44(\mathrm{~m}, 4 \mathrm{H}), 1.52-1.60(\mathrm{~m}, 6 \mathrm{H})$, $1.72-1.79(\mathrm{~m}, 1 \mathrm{H}), 1.80-1.86(\mathrm{~m}, 1 \mathrm{H}), 3.01(\mathrm{~s}, 3 \mathrm{H}), 3.39(\mathrm{dt}$, $1 \mathrm{H}, J=9.6 \mathrm{~Hz}, J=6.4 \mathrm{~Hz}), 3.48-3.53(\mathrm{~m}, 1 \mathrm{H}), 3.74(\mathrm{dt}, 1 \mathrm{H}, J=$ $9.6 \mathrm{~Hz}, J=6.7 \mathrm{~Hz}), 3.84-3.89(\mathrm{~m}, 1 \mathrm{H}), 4.23(\mathrm{t}, 2 \mathrm{H}, J=6.5 \mathrm{~Hz})$, $4.57(\mathrm{tz} 1 \mathrm{H}, J=2.6 \mathrm{~Hz}) \mathrm{ppm} .{ }^{13} \mathrm{C} \mathrm{NMR}\left(\mathrm{CDCl}_{3}, 100 \mathrm{MHz}\right)$ : $\delta 19.71,25.27,25.44,25.72,29.05,29.50,30.74,37.34,62.44$, 67.32, 70.01, 98.92 ppm. LRMS (ESI) $m / z 303.0[\mathrm{M}+\mathrm{Na}]^{+}$.

Procedure for the Synthesis of 1-[3-(pyridin-3-yl)propoxy]6-(oxan-2-yloxy)hexane (4)

A mixture of 3-(pyridin-3-yl)propan-1-ol (1.0 equiv.) and $\mathrm{Bu}_{4} \mathrm{~N}^{+} \mathrm{Br}^{-}$(0.33 equiv.) was prepared in $20 \mathrm{~mL}$ of $\mathrm{Et}_{2} \mathrm{O}$ with 5 $\mathrm{mL}$ of aqueous $\mathrm{NaOH}(50 \% \mathrm{v} / \mathrm{v})$ and stirred for 15 minutes. After this period, the mesylated compound 3 (1.0 equiv.) was added. The mixture was stirred vigorously at room temperature for 72 hours and then extracted with $\mathrm{Et}_{2} \mathrm{O}(3$ times). The combined organic layers were dried with $\mathrm{Na}_{2} \mathrm{SO}_{4}$, filtered, and evaporated under reduced pressure. The residue obtained was chromatographed $\left(\mathrm{SiO}_{2}\right.$, hexane/EtOAc $\left.1: 1\right)$ to yield pure compound 4 .

1-[3-(pyridin-3-yl)propoxy]-6--(oxan-2-yloxy)hexane 4: Yield $60 \%, R f=0.44$ (hexane/EtOAc 1:1), yellow oily product: IR (KBr): $\bar{v}=2929,2865,1456,1421,1124,1120,983,857$ $\mathrm{cm}^{-1} .{ }^{1} \mathrm{H}$ NMR $\left(\mathrm{CDCl}_{3}, 400 \mathrm{MHz}\right): \delta 1.30-1.43$ (m, 8H), $1.50-$ $1.63(\mathrm{~m}, 4 \mathrm{H}), 1.66-1.75(\mathrm{~m}, 1 \mathrm{H}), 1.79-1.92(\mathrm{~m}, 1 \mathrm{H}), 2.70(\mathrm{t}$, $2 \mathrm{H}, J=7.4 \mathrm{~Hz}), 3.38-3.43(\mathrm{~m}, 5 \mathrm{H}), 3.47-3.53(\mathrm{~m}, 1 \mathrm{H}), 3.74(\mathrm{dt}$, $1 \mathrm{H}, J=9.6 \mathrm{~Hz}, J=6.8 \mathrm{~Hz}), 3.84-3.90(\mathrm{~m}, 1 \mathrm{H}), 4.58(\mathrm{t}, 1 \mathrm{H}, J=$ $2.6 \mathrm{~Hz}), 7.19-7.23(\mathrm{~m}, 2 \mathrm{H}), 7.52(\mathrm{~d}, 2 \mathrm{H}, J=7.8 \mathrm{~Hz}), 8.43-8.46$ $(\mathrm{m}, 2 \mathrm{H}) \mathrm{ppm} .{ }^{13} \mathrm{C} \mathrm{NMR}\left(\mathrm{CDCl}_{3}, 100 \mathrm{MHz}\right): \delta 19.67,25.45$, 26.09, 29.48, 29.67, 30.74, 30.97, 62.33, 67.53, 69.40, 70.94, $98.83,123.22,135.84,137.19,147.27,149.97$ ppm. HRMS $[\mathrm{M}+\mathrm{Na}]^{+}=344.2193$ (theoretical 344.2202).

Procedure for the Synthesis of 6-[3-(pyridin-3-yl)propoxy] hexan-1-ol (5)

To a solution of compound 4 (1.0 equiv.) in $\mathrm{MeOH}(50 \mathrm{~mL})$ was added $3.36 \mathrm{~mL}$ of $1 \mathrm{M} \mathrm{HCl}$ (2.0 equiv.). After the addition, the reaction was stirred for 12 hours at room temperature, and the solution was concentrated under reduced pressure. Equal volumes of EtOAc and distilled water were added, and the $\mathrm{pH}$ was brought to 10 with the addition of $2 \mathrm{M} \mathrm{NaOH}$. The solution was then extracted with EtOAc (3 times). The combined organic layers were dried with $\mathrm{Na}_{2} \mathrm{SO}_{4}$, filtered, and evaporated under reduced pressure. The residue obtained was chromatographed $\left(\mathrm{SiO}_{2}\right.$, EtOAc 1:1) to yield pure compound 5 .

6-[3-(pyridin-3-yl)propoxy]hexan-1-ol 5: Yield 70\%, $R f=$ 0.33 (EtOAc), yellow oily product: IR (KBr): $\bar{v} 3348,2927$, 2854, 1457, 1423, 1357, 1130, 1114, 985, $856 \mathrm{~cm}^{-1} .{ }^{1} \mathrm{H}$ NMR $\left(\mathrm{CDCl}_{3}, 400 \mathrm{MHz}\right): \delta 1.23-1.42(\mathrm{~m}, 4 \mathrm{H}), 1.56-1.63(\mathrm{~m} .4 \mathrm{H})$, $1.89(\mathrm{~m}, 2 \mathrm{H}), 2.71(\mathrm{t}, 2 \mathrm{H}, J=7.4 \mathrm{~Hz}), 3.38-3.42(\mathrm{~m}, 4 \mathrm{H}), 3.65$ $(\mathrm{t}, 2 \mathrm{H}, J=6.5 \mathrm{~Hz}), 7.20-7.24(\mathrm{~m}, 1 \mathrm{H}), 7.52(\mathrm{~d}, 1 \mathrm{H}, J=7.8$ $\mathrm{Hz}), 8.42-8.45$ (m, 2H) ppm. ${ }^{13} \mathrm{C} \mathrm{NMR}\left(\mathrm{CDCl}_{3}, 100 \mathrm{MHz}\right)$ : $\delta 25.53,25.95,29.40,29.61,30.85,32.70,62.66,69.28,70.80$, $123.30,135.97,137.22,147.12,149.86 \mathrm{ppm}$. HRMS $[\mathrm{M}+\mathrm{H}]^{+}=$ 238.1801 (theoretical 238.1807).

Procedure for the Synthesis of 3-(3-((6-chlorohexyl)oxy) propyl)pyridine (6)

To a solution of NCS (1.1 equiv.) dissolved in $\mathrm{CH}_{2} \mathrm{Cl}_{2}$, cooled at $0^{\circ} \mathrm{C}$, and under inert atmosphere, a solution of $\mathrm{PPh}_{3}(1.1$ equiv.) dissolved in $\mathrm{CH}_{2} \mathrm{Cl}_{2}$ was added. This solution was stirred for $10 \mathrm{~min}$ followed by the addition of a solution of compound 5 (1.0 equiv.). The solution was allowed to warm to room temperature and stirred for 18 hours. After this period, the solvent was evaporated under reduced pressure. Subsequently, a small volume of $\mathrm{Et}_{2} \mathrm{O}$ was added; the recipient was placed in the refrigerator for precipitation of $\mathrm{PPh}_{3}$. The mixture was filtered and evaporated. The residue was purified by column chromatography $\left(\mathrm{SiO}_{2}, \mathrm{EtOAc} / \mathrm{MeOH} 95: 5\right)$ to yield pure compound 6 .

3-(3-((6-chlorohexyl)oxy)propyl)pyridine 6: Yield 11\%, $R f$ $=0.75$ (EtOAc), yellow oily product: IR (KBr): $\bar{v}$ 2850, 2950, $1710,1480,1410,1125,1175,1025,700,640 \mathrm{~cm}^{-1} .{ }^{1} \mathrm{H}$ NMR $\left(\mathrm{CDCl}_{3}, 400 \mathrm{MHz}\right): \delta 1.44-1.66(\mathrm{~m}, 4 \mathrm{H}), 1.82-1.99(\mathrm{~m}, 4 \mathrm{H})$, $1.64(\mathrm{q}, 2 \mathrm{H}, J=6.6 \mathrm{~Hz}) ; 2.77(\mathrm{t}, 2 \mathrm{H}, J=8.0 \mathrm{~Hz}), 3.47(\mathrm{t}, 4 \mathrm{H}, J$ $=6.3 \mathrm{~Hz}), 3.6(\mathrm{t}, 2 \mathrm{H}, J=6.7 \mathrm{~Hz}), 7.29(\mathrm{t}, 1 \mathrm{H}, J=4.8 \mathrm{~Hz}), 7.61$ $(\mathrm{d}, 1 \mathrm{H}, J=1.7 \mathrm{~Hz}), 8.52(\mathrm{~d}, 2 \mathrm{H}, J=4.3 \mathrm{~Hz}) \mathrm{ppm} .{ }^{13} \mathrm{C} \mathrm{NMR}$ $\left(\mathrm{CDCl}_{3} 100 \mathrm{MHz}\right): \delta 25.49,26.67,29.46,29.52,29.59,30.90$, $32.50,45.02,69.44,123.31,136.06,137.29,147.03,149.69$ ppm. LRMS (ESI) $(m / z): 256.3[\mathrm{M}+\mathrm{H}]^{+}$.

Procedure for the Synthesis of 3-(3-((6-fluorohexyl)oxy) propyl)pyridine (7)

To a solution of compound 5 (1.0 equiv.) dissolved in $\mathrm{CH}_{2} \mathrm{Cl}_{2}$, cooled at $-60^{\circ} \mathrm{C}$, and under inert atmosphere, 1.2 equiv. of Diethylamino sulfur trifluoride (DAST) was added. This solution was stirred for 2 hours and cooled at $-60^{\circ} \mathrm{C}$. After that, it was allowed to warm to room temperature and stirred for 18 hours (overnight). After this period, $5 \mathrm{~mL}$ of water was added to quench the DAST excess. Then, the reaction mixture was washed with a diluted solution of $\mathrm{NaHCO}_{3}(5 \mathrm{w} / \mathrm{v} \%)$ and water. The organic layer was dried $\left(\mathrm{Na}_{2} \mathrm{SO}_{4}\right)$, filtered, and evaporated under reduced pressure. The residue obtained was purified by column chromatography $\left(\mathrm{SiO}_{2}, \mathrm{EtOAc}\right)$ to yield 
pure compound 7.

3-(3-((6-fluorohexyl)oxy)propyl)pyridine 7: Yield 6\%, $R f=$ 0.40 (EtOAc), yellow oily product: IR (KBr): $\bar{v}$ 2927, 2860, $1737,1641,1463,1354,1257,1242,1172,1026,974,935,908$, $748,713,526,459,403 \mathrm{~cm}^{-1} .{ }^{1} \mathrm{H}$ NMR $\left(\mathrm{CDCl}_{3}, 400 \mathrm{MHz}\right): \delta$ 1.41-1.43 (m, $4 \mathrm{H}), 1.57-1.70(\mathrm{~m}, 4 \mathrm{H}), 1.86-1.93(\mathrm{~m}, 2 \mathrm{H}), 2.68-$ $2.72(\mathrm{t}, 2 \mathrm{H}, J=8.0 \mathrm{~Hz}), 3.39-3.43(\mathrm{t}, 4 \mathrm{H}, J=8.0 \mathrm{~Hz}), 4.45(\mathrm{dt}$, $\left.2 \mathrm{H},{ }^{2} J_{H F}=48.0 \mathrm{~Hz},{ }^{3} \mathrm{~J}_{H H}=8.0 \mathrm{~Hz}\right), 7.19-7.23(\mathrm{~m}, 1 \mathrm{H}), 7.50-7.52$ $(\mathrm{d}, 1 \mathrm{H}, J=8.0 \mathrm{~Hz}), 8.43-8.45(\mathrm{~m}, 2 \mathrm{H}) \mathrm{ppm} .{ }^{13} \mathrm{C} \mathrm{NMR}\left(\mathrm{CDCl}_{3}\right.$, $100 \mathrm{MHz}): \delta 25.09,25.87,29.50,29.62,30.26,30.96,64.48$, $70.84,84.1\left(\mathrm{~d}, J_{1}=162.0 \mathrm{~Hz}\right), 123.27,135.89,137.22,147.31$, 149.99 ppm.

\section{In Vitro Schizonticidal Antiplasmodial Activity}

Plasmodium falciparum chloroquine-resistant (W2) strain was maintained in continuous culture using human red blood cells in RPMI 1640 medium supplemented with human plasma. ${ }^{10}$ Human red blood cells and human plasma were provided by the Foundation of Hemotherapy and Hemathology of Minas Gerais (Fundação Hemominas). Parasites were synchronized using sorbitol treatment, ${ }^{11}$ and the parasitemias were evaluated microscopically with Giemsa solution-stained blood smears. Antiplasmodial activity was determined using an ELISA anti-HRPII assay. ${ }^{12}$ Briefly, a 96well plate was coated with infected red blood cells at $0.05 \%$ parasitemia and 1.5\% hematocrit. Different concentrations of the compounds were added in triplicate, and twelve compound-free wells were used as controls ( 6 frozen after 24 hours as the HRPII background). After incubation (72 hours), the plate was frozen and thawed twice, and an ELISA using anti-HRPII antibodies was performed. The results were expressed as the mean of the half-maximal inhibitory dose $\left(\mathrm{IC}_{50}\right)$ of three assays with different drug concentrations performed in triplicate, compared with drug-free controls. Curve fitting was performed using OriginPro 8.0 software (Origin Lab. Corporation, Northampton, MA, USA).

\section{In Vitro Cytotoxicity Test}

The noncancerous human lung fibroblast cell line WI-26 VA4 (ATCC CCL-95.1) was used to assess cell viability after each chemical treatment employing the MTT colorimetric assay. ${ }^{13}$ Briefly, $1 \times 10^{6}$ cells were plated in 96-well plates with RPMI 1640 medium supplemented with fetal bovine serum (FBS) and penicillin-streptomycin antibiotics. Then, plates were incubated overnight at $37^{\circ} \mathrm{C}, 5 \% \mathrm{CO}_{2}$, followed by treatment with each compound solubilized in DMSO $0.1 \%(\mathrm{v} / \mathrm{v})$. Negative control groups were constituted of cells without treatment. Five serial dilutions $(1: 10)$ were made from a stock solution (10 $\mathrm{mg} \mathrm{mL}^{-1}$ ) using RPMI supplemented with $1 \%$ FBS. After 48 hours of incubation, cell viability was evaluated by discarding the medium and adding $100 \mu \mathrm{L}$ of MTT $5 \%$, followed by $3 \mathrm{~h}$ of incubation. Then, the supernatant was discarded and the insoluble formazan product was dissolved in DMSO. The optical density (OD) of each well was measured using a microplate spectrophotometer at $550 \mathrm{~nm}$. The OD in untreated control cells was defined as $100 \%$ cell viability. All assays were performed in triplicate. The selectivity index (SI) of the 3-APA analogs was calculated as: $\mathrm{SI}=\mathrm{IC}_{50} \mathrm{WI}-26 \mathrm{VA} 4 /$
$\mathrm{IC}_{50} P$. falciparum.

Statistical Analysis

Analysis of variance (ANOVA) was performed followed by the Tukey-Kramer multiple comparisons post-test with a significance level of 0.05 . Statistical analysis was performed using OriginPro 8.0 software (Origin Lab. Corporation, Northampton, MA, USA).

\section{Heme Binding Experiments}

Heme titration experiments were carried out in a UV-Vis spectrophotometer (Thermo Scientific, Model Genesys 10S) using $1 \mathrm{~cm}$ path cuvettes. Preparation of Heme Stock Solution: A $1.61 \mathrm{mM}$ heme stock solution was prepared by dissolving $10.5 \mathrm{mg}$ of hematin chloride in $1 \mathrm{~mL}$ of DMSO. Preparation of Ligands Stock Solution: Concentrated solutions of 22.78 $\mathrm{mM}, 131.0 \mathrm{mM}, 57.2 \mathrm{mM}$, and $10.45 \mathrm{mM}$ of ligand stock solution were prepared by dissolving $5.4 \mathrm{mg}, 33.5 \mathrm{mg}, 13.7$ $\mathrm{mg}$, and $10.0 \mathrm{mg}$ of compounds 5, 6, 7, and chloroquine, respectively, in $1 \mathrm{~mL}$ of DMSO. Buffer: A $0.020 \mathrm{M}$ HEPES $40 \%$ DMSO buffer with an apparent $\mathrm{pH}$ value of 7.4 was prepared by adding $100 \mathrm{~mL}$ DMSO and $5 \mathrm{~mL}$ of $1 \mathrm{M}$ HEPES, comprising a final volume of $250 \mathrm{~mL}$ of distilled water. The solution was stored at $4^{\circ} \mathrm{C}$. Titration Experiments: $5 \mu \mathrm{M}$ of heme solution was prepared from the concentrated stock solution (1.61 mM) using HEPES buffer. Solutions of $0.5 \mathrm{mM}$ of ligands 5 and $6 ; 2.0 \mathrm{mmol} \mathrm{L}^{-1}$ of ligand 7 and chloroquine were prepared from concentrated solutions dissolved in 5 $\mu \mathrm{M}$ heme solution to avoid dilution effects. Titrations were performed by adding small volumes of the ligand solutions to a $5.0 \mu \mathrm{M}$ heme solution, varying the concentrations of the ligands from 0 to $5.24 \mu \mathrm{M}$, from 0 to $200.9 \mu \mathrm{M}$, from 0 to $766.9 \mu \mathrm{M}$, and from 0 to $161.0 \mu \mathrm{M}$ for compounds $5,6,7$, and chloroquine, respectively. After each addition, the absorbance was measured from $300 \mathrm{~nm}$ to $500 \mathrm{~nm}$. All experiments were performed in triplicate. Curve fitting was performed using GraphPad Prism 5.01 software.

\section{Results}

Chemistry

Compounds 6 and 7 were obtained in five steps from the available starting materials as shown in Scheme 1. The synthesis of compounds 1 to 5 was described previously. ${ }^{14}$ In brief, 1,6-hexanediol 1 was selectively monoprotected to generate the corresponding monotetrahydropyranyl acetal 2 . Compound 2 was then mesylated using traditional conditions, resulting in compound 3. Next, Williamson etherification was performed under phase-transfer catalysis of commercially available 3-(pyrid-3-yl) propan-1-ol with compound 3 to give compound 4 . Then, a deprotection was performed using $\mathrm{HCl}$, affording compound 5. Finally, the hydroxyl group of compound 5 was substituted by a chlorine and a fluorine atom using N-chlorosuccinimide and DAST to afford compounds 6 and 7 , respectively.

To optimize the antiplasmodial activity of compound 5, analogs 6 and 7 were obtained through halogenation. These compounds had their in vitro growth inhibitory activity evaluated against a chloroquine resistant strain of $P$. falciparum (clone W2) with chloroquine as a positive control. 
Additionally, both compounds were tested in vitro against the human cell line WI-26 VA4 (noncancerous human lung fibroblast cell line) to evaluate their cytotoxicity (techniques are described in Supporting Information, items 2 and 3).

As depicted in Table 1, halogenation by inserting chlorine and fluorine in compounds 6 and 7, respectively, was found to improve their antiplasmodial activity $(7.2 \mu \mathrm{M}$ and $8.3 \mu \mathrm{M}$, respectively) to about 25 times higher than that of compound $5(210.7 \mu \mathrm{M})$. Interestingly, both compounds were less toxic to the human cell line than compound 5, which was demonstrated by an increase in the selectivity index (SI) from 1.9 (compound 5) to 4.5 (compound 6) and 35.1 (compound 7 ). The insertion of a fluorine atom in compound 7 led to a higher selectivity to $P$. falciparum.

\section{Discussion}

Improvement in biological activity as a result of halogenation has been used by the pharmaceutical industry and noted by other researchers during hit-to-lead or lead-to-drug conversions. ${ }^{15,} 16$ The incorporation of halogenation atoms can improve metabolic stability, ${ }^{17}$ enhance membrane permeability, ${ }^{18}$ and favor molecular recognition between ligands and its receptors through the formation of halogen bonds. ${ }^{19}$

Moreover, as compounds 6 and 7 exhibited good in vitro activity against $P$. falciparum, they are candidates for further in vivo studies in the near future. The observation of the in vivo acute toxicity and efficacy data of these compounds is one more critical step to improving their likelihood of clinical success. This and other clinical data could support the development of a new antimalarial formulation to treat affected people.

Once the biological activity of compounds 6 and 7 was verified, the next step was to determine if halogenation altered the mechanism of action of the series. Inhibition of hematin polymerization was investigated by UV-Vis spectroscopy (Supporting Information, item 4). This method was chosen, because it can detect free hematin in submicromolar concentrations, as in the parasite's digestive vacuole. ${ }^{20}$ An absorption band (Soret band) at $401 \mathrm{~nm}$ indicates the presence of free hematin, and a decrease in the intensity of the Soret band indicates the formation of a complex between hematin and the tested compound. ${ }^{21}$ As shown in Figures 1a and 1b, compound 5 exhibited an interaction pattern with hematin similar to that of CQ.

UV-Vis titration experiments confirmed that the replacement of the hydroxyl group in compound 5 with chlorine or fluorine atoms (in compounds 6 and 7 ,

Table 1. In Vitro Antiplasmodial Activities, Cytotoxicities, and Selectivity Indices of Chloroquine and Compounds 5, 6, and 7

\begin{tabular}{lccc}
\hline \multirow{2}{*}{ Compound } & \multicolumn{2}{c}{$\mathbf{I C}_{\mathbf{5 0}}(\boldsymbol{\mu M})\left(\right.$ mean $\left.\pm \mathbf{S D}^{\mathbf{a}}\right)$} & \multirow{2}{*}{$\mathbf{S I}^{\mathbf{b}}$} \\
\cline { 2 - 3 } & $\boldsymbol{P}$ falciparum $(\mathbf{W} \mathbf{2})$ & $\mathbf{W I - 2 6 ~ V A 4}$ & \\
\hline $\mathbf{5}$ & $210.7 \pm 18.1$ & $421.3 \pm 12.7$ & 1.9 \\
$\mathbf{6}$ & $7.2 \pm 1.2^{*}$ & $32.3 \pm 2.8^{*}$ & 4.5 \\
$\mathbf{7}$ & $8.3 \pm 2.0^{*}$ & $291.7 \pm 15.4^{*}$ & 35.1 \\
$\mathbf{C Q}$ & $0.4 \pm 0.07^{*}$ & $>100$ & $>270$ \\
\hline
\end{tabular}

Research Highlights

What Is Already Known?

- Malaria is a disease that affects millions of people worldwide;

- The emergence of resistance to antimalarials is a great concern;

- Many attempts to discover new antimalarials has been made over the years.

\section{What This Study Adds?}

- 3-Alkylpyridine marine alkaloid (3-APA) analog corresponds to a new scaffold which has promising antimalarial activity;

- Halogenation is an interesting approach, because it leads to enhanced antimalarial activity and selectivity;

- Halogenated 3-APA analogs inhibited hemozoin formation, similar to the chloroquine mechanism of action.

respectively) did not alter the ability of these compounds to form a complex with hematin. As shown in Figures $1 \mathrm{c}$ and 1d, the Soret band intensity was decreased with compounds 6 and 7 , indicating the formation of a complex with hematin. Similar results in the presence of antimalarial candidates have also been reported by other researchers. ${ }^{22}$ Thus, compounds 5, 6 , and 7 exhibited similar patterns of hematin binding (Figures $1 \mathrm{~b}, 1 \mathrm{c}$, and 1d, respectively). However, it is still not clear whether halogenation improves antiplasmodial activity by enhancing membrane permeability or molecular recognition.

All the data collected in this work suggests that compound 7 is a good starting point for further chemical optimization. However, according to Katsuno et $\mathrm{al}^{23}$ a compound to be assayed in vivo should fulfill specific requirements, such as $\mathrm{IC}_{50}<100 \mathrm{nM}$ against $P$. falciparum strains and SI greater than 100 fold against mammalian cell lines.

\section{Conclusion}

A simple substitution of the hydroxyl group in a compound by a halogen atom can lead to significant changes in its antiplasmodial activity without altering its ability to bind to the target. However, it is still necessary to verify the effects of halogenation in these compounds; thus, further studies are necessary. As it has been shown before, this approach combined with reports of successful oriented synthesis and molecular hybridization could be an attractive alternative for the optimization of potential new antimalarial candidates. Therefore, further lead optimization of the halogenated compound 7 is required as it might identify new potential antimalarial candidates.

\section{Authors' Contributions}

Synthesis and structural elucidation: CdeSB and JdaCA; Performed the biological experiments: DSMG and CFAdeB; Biophysical heme binding study: RMRV and CdeSB; Coordinated the research: FdePV and GHRV. The manuscript was written with the contributions of all authors.. 


\section{Conflict of Interest Disclosures}

The authors declare that they have no conflicts of interest.

\section{Ethical Approval}

Not applicable. The assays were not performed in humans or animals.

\section{Acknowledgments}

The authors would like to acknowledge the financial support received from Fundação de Amparo e Pesquisa do Estado de Minas Gerais (APQ-01597-14, APQ-01598-15), Conselho Nacional de Desenvolvimento Científico e Tecnológico (402733/2016-9), and Coordenação de Aperfeiçoamento de Pessoal de Nível Superior (CAPES). The authors would also like to thank Laboratório de Espectroscopia and Laboratório de Análise de Materiais e Moléculas, Universidade Estadual de Londrina/Financiadora de Estudos e Projetos (CT INFRA 2009-01.10.0534.01 and CT-INFRA-2011-01.13.0049.00) for the UV-vis experiments.

\section{References}

1. World Health Organization (WHO). World malaria report 2018. WHO; 2018.

2. Pan American Health Organization (PAHO), World Health Organization (WHO). Epidemiological update increase of malaria in the Americas. PAHO, WHO; 2018.

3. Cox-Singh J. Plasmodium knowlesi: experimental model, zoonotic pathogen and golden opportunity? Parasitology. 2018;145(1):1-5. doi:10.1017/s0031182017001858.

4. Langlais D, Cencic R, Moradin N, et al. Rocaglates as dual-targeting agents for experimental cerebral malaria. Proc Natl Acad Sci U S A. 2018;115(10):E2366-E2375. doi:10.1073/pnas.1713000115.

5. Zuber JA, Takala-Harrison S. Multidrug-resistant malaria and the impact of mass drug administration. Infect Drug Resist. 2018;11:299-306. doi:10.2147/idr.s123887.

6. Ashley EA, Phyo AP. Drugs in development for malaria. Drugs. 2018;78(9):861-879. doi:10.1007/s40265-018-0911-9.

7. Hilário FF, de Paula RC, Silveira ML, et al. Synthesis and evaluation of antimalarial activity of oxygenated 3-alkylpyridine marine alkaloid analogues. Chem Biol Drug Des. 2011;78(3):477-482. doi:10.1111/j.1747-0285.2011.01154.x.

8. Ribeiro-Viana RM, Butera AP, Santos ES, et al. Revealing the binding process of new 3-Alkylpyridine marine alkaloid analogue antimalarials and the heme group: an experimental and theoretical investigation. J Chem Inf Model. 2016;56(3):571-579. doi:10.1021/acs.jcim.5b00742.

9. Nicolaou KC. Advancing the drug discovery and development process. Angew Chem Int Ed. 2014;53(35):9128-9140. doi:10.1002/anie.201404761.
10. Trager W, Jensen JB. Human malaria parasites in continuous culture. Science.1976;193(4254):673-675.doi:10.1126/science.781840.

11. Lambros C, Vanderberg JP. Synchronization of Plasmodium falciparum erythrocytic stages in culture. J Parasitol. 1979;65(3):418-420. doi:10.2307/3280287.

12. Noedl H, Wernsdorfer WH, Miller RS, Wongsrichanalai C. Histidine-rich protein II: a novel approach to malaria drug sensitivity testing. Antimicrob Agents Chemother. 2002;46(6):1658-1664. doi:10.1128/aac.46.6.1658-1664.2002.

13. Carmichael J, DeGraff WG, Gazdar AF, Minna JD, Mitchell JB. Evaluation of a tetrazolium-based semiautomated colorimetric assay: assessment of chemosensitivity testing. Cancer Res. 1987;47(4):936-942.

14. Gonçalves AM, de Lima AB, da Silva Barbosa MC, et al. Synthesis and biological evaluation of novel 3-alkylpyridine marine alkaloid analogs with promising anticancer activity. Mar Drugs. 2014;12(8):4361-4378. doi:10.3390/md12084361.

15. Swallow S. Fluorine in medicinal chemistry. Prog Med Chem. 2015;54:65-133. doi:10.1016/bs.pmch.2014.11.001.

16. Jia F, Zhang Y, Wang J, et al. The effect of halogenation on the antimicrobial activity, antibiofilm activity, cytotoxicity and proteolytic stability of the antimicrobial peptide Jelleine-I. Peptides. 2019;112:56-66. doi:10.1016/j.peptides.2018.11.006.

17. Obach RS, Walker GS, Brodney MA. Biosynthesis of fluorinated analogs of drugs using human cytochrome P450 enzymes followed by deoxyfluorination and quantitative nuclear magnetic resonance spectroscopy to improve metabolic stability. Drug Metab Dispos. 2016;44(5):634-646. doi:10.1124/dmd.116.069310.

18. Gerebtzoff G, Li-Blatter X, Fischer H, Frentzel A, Seelig A. Halogenation of drugs enhances membrane binding and permeation. Chembiochem. 2004;5(5):676-684. doi:10.1002/ cbic. 200400017.

19. Hernandes MZ, Cavalcanti SM, Moreira DR, de Azevedo Junior WF, Leite AC. Halogen atoms in the modern medicinal chemistry: hints for the drug design. Curr Drug Targets. 2010;11(3):303-314. doi:10.2174/138945010790711996.

20. Goldberg DE, Slater AF, Cerami A, Henderson GB. Hemoglobin degradation in the malaria parasite Plasmodium falciparum: an ordered process in a unique organelle. Proc Natl Acad Sci U S A. 1990;87(8):2931-2935. doi:10.1073/pnas.87.8.2931.

21. Kumar G, Tanwar O, Kumar J, et al. Pyrazole-pyrazoline as promising novel antimalarial agents: a mechanistic study. Eur J Med Chem. 2018;149:139-147. doi:10.1016/j.ejmech.2018.01.082.

22. Goyal M, Singh P, Alam A, et al. Aryl aryl methyl thio arenes prevent multidrug-resistant malaria in mouse by promoting oxidative stress in parasites. Free Radic Biol Med. 2012;53(1):129142. doi:10.1016/j.freeradbiomed.2012.04.028.

23. Katsuno K, Burrows JN, Duncan K, et al. Hit and lead criteria in drug discovery for infectious diseases of the developing world. Nat Rev Drug Discov. 2015;14(11):751-758. doi:10.1038/nrd4683. 